\title{
Impact of Corporate Agriculture on Sustainable Rural Development in Nigeria
}

\author{
Eneji Mathias Agri ${ }^{1,2 *}$, Odey Francis Acha ${ }^{3}$, Gukat Olivia Bonmwa Tontu ${ }^{1}$ \\ ${ }^{1}$ Department of Economics, University of Jos, Jos, Nigeria \\ ${ }^{2}$ China-Africa Science and Technology Foundation, Beijing, China \\ ${ }^{3}$ Nigeria's Ministry of Foreign Affairs, FCT, Nigeria \\ Email: "agrieneji@yahoo.com
}

Received 3 April 2016; accepted 18 April 2016; published 21 April 2016

Copyright (C) 2016 by authors and OALib.

This work is licensed under the Creative Commons Attribution International License (CC BY). http://creativecommons.org/licenses/by/4.0/

(c) $\underset{\mathrm{EY}}{\mathrm{BY}}$ Open Access

\begin{abstract}
This study sets out to investigate whether corporate agriculture has any significant impact on Nigeria's economy. The dimensions of impact assessed are mainly capital investment, private sector's participation, employment and rural resource/infrastructural development. We used descriptive statistics and simple percentages for evaluation. Secondary data from the Nigerian Stock Exchange were collected, sorted, classified and used for the analysis, with extensive literature review. The study finds that corporate agriculture has significant positive impact on the economy, but the subsector is still under-invested and under-utilized. Government policies had not encouraged large scale investment in corporate agriculture; rather it has only favored official funding of agricultural programs creating loopholes for mismanagement of huge agricultural resources and wastages. The implications are obvious; including unemployment, food insecurity and rural poverty. Our limitation is with respect to inaccurate, up-to-date secondary data. However, this limitation does not invalidate our findings. We recommend corporate agriculture, policy reforms and accelerated investment in the sector through public-private partnership. We also recommend a bridge in infrastructure gap between rural and urban geography in a comprehensive rural-urban integration program. We conclude that Nigeria can achieve food security and also contribute to food security in other countries through exports and foreign exchange.
\end{abstract}

\section{Keywords}

Agricultural Industry, Local Content, Capital Allocation, Returns on Investment, Employment and Poverty Reduction

Subject Areas: Economics

${ }^{*}$ Corresponding author.

How to cite this paper: Agri, E.M., Acha, O.F. and Tontu, G.O.B. (2016) Impact of Corporate Agriculture on Sustainable Rural Development in Nigeria. Open Access Library Journal, 3: e2503. http://dx.doi.org/10.4236/oalib.1102503 


\section{Introduction}

The purpose of this study is to investigate whether corporate agriculture has any significant impact on rural development in Nigeria. The dimensions of impact assessed include employment, rural resource development, GDP, capital investment and private sector (corporate bodies') participation. Given Nigeria's huge population, and the consequences of unemployment on the economy and individuals, it is not out of place to consider corporate agriculture as a veritable tool for poverty reduction and rural development in Nigeria. Government alone cannot provide the needed jobs, but private investment in labour-intensive corporate agriculture can. It is imperative for the private sector to be encouraged by government policy to invest in the upstream and downstream agribusiness in Nigeria. A lesson was learnt from a field survey undertaken in China's agro-industries, particularly the Chateau Chanyu Wine Industry and Dabeinong High-Tech Agricultural Industry. Chateau Chanyu was listed in China's stock market, like many of Chinese agricultural companies. The industry has a long history of corporate agribusiness and collaboration with similar industries in Germany, Australia, France, Italy, Newzealand etc.

The wine industry has a large scale farming technology. It grows grapes, manufactures and exports first grade wine to several countries with lots of employment and poverty reduction drive. This is possible for the Nigerian cocoa, palm oil, saw mills, groundnut, fruits, and rice, cassava, cotton and textile industries. Their propensity to create jobs and generate income is higher than the oil industry. As income increases for the poor, together with high rural savings rates, it makes capital available for investment. Agricultural research helped the wine-grape growers, food technology and investment programs helped the wine makers. Infrastructure and employment over the entire area have significantly improved. Chinese Government also encouraged the industry with market information to expand domestic and foreign markets. Nigeria can demonstrate high level policy commitment to rural industry promotion in agriculture and tourism, translated into network systems of subsidized inputs, liberalized incentives, policy protection, quotas, and promotional institutions, favoring corporate large scale and medium scale agriculture value-added. The rural communities in some regions such as North-East, North-West, South-South etc. have specific endowments, but face risks of insurgency and natural disasters like drought and flood which reduce their crop yield and livestock production. These risks make the rural farmers very vulnerable to the loss of their income sources. The disasters work for corporate agriculture and agro-industrial diversification in order to mitigate the risk of farm failures, and evolve a balanced, inclusive development. The small scale farmers do not have the resilience to recover quickly from such disasters in the absence of alternative sources of capital/income, especially in the absence of credit and insurance markets in the rural areas. Nigeria is running out of her oil resources and needs to preserve these oil resources by harnessing properly her non-oil resources. This study considers corporate agricultural enterprises as a veritable tool for poverty reduction and rural development in Nigeria due to the local resource content, labor and capital input that are likely to be absorbed. In modern societies, stock exchange performs important development roles for any country. One of these roles is the conduit of investment capital. The problem of study highlighted in the next section, and the expected benefits are the determinants of corporate and agro-diversification. Corporate agriculture can work very successfully in Nigeria, given the capital and a strong incentive to diversify investments in order to secure farmers' livelihoods. Corporate agriculture can play a key role in the livelihood strategies of the Nigerian youths and the rural poor. Besides, the managerial skills, production and marketing skills are getting highly professional and competitive beyond subsistence agriculture. These require pulling together of resources to be professionally harnessed in a large scale. The economies of scale from corporate agriculture in terms of financial capital, inputs, research and sustainable development, employment and profits cannot be overestimated. The need to raise capital from the Nigerian stock Exchange Market for commercial agriculture cannot be overemphasized. Investors in Nigeria's agriculture should expect huge financial returns.

This study is organized in 6 sections. Section 1 is the introduction. Section 2 is the problem and significance of study. It covers also literature review. Section 3 is the methodology. Discussion of findings is in section 4, while sections 5 and 6 are the conclusion and recommendation respectively.

\section{Problem and Significance of Study}

\subsection{Problem of Study}

Nigeria is ranked 26th economy in the world [1], and the largest economy in Africa. The country is also on track 
to become one of the 20 largest economies in the world by 2020. However, Nigeria's subsistence agricultural sector and continued importation of what she could naturally produce have not kept pace with economic vision. The country has had several Agricultural policies from the 1970's to date, characterized by political instability and policy inconsistency as well as lack of political will to sincerely implement these policies. Worse still, all the agricultural programs depend wholly on official funding crippled by official corruption. Adequate consideration and policy incentives have not been given to the private sector's corporate investment in Nigeria's most endowed sector-agriculture. Given Nigeria's population, poverty affects about $45 \%$ of the population, in contrast with huge wastages and vast untapped resource potentials resulting to resource curse. The economy suffers basic deficiencies including unreliable power supply, decaying infrastructure and corruption which are impediments to private enterprise development. There are difficulties in assessing credit facilities for investment in agriculture. Others are land grabbing, small scale production and lack of awareness of inherent potential in the industry. Above all, the agricultural industry which Nigeria has comparative advantage, is yet to be properly listed in the Nigeria's Stock Exchange (NSE). Besides, Nigeria's agriculture has suffered from years of mismanagement, inconsistent and poorly conceived government policies, neglect and lack of basic infrastructure. Nigeria is no longer a major exporter of cocoa, groundnut, rubber, oil palm mostly caused by lack of research, obsolete varieties and overage trees. The land tenure system does not encourage long-term investment in technology or modern production innovations. Nigeria which was a net exporter of food has become a net importer of food to sustain her teaming population. This is absolutely not sustainable. The average percentage contribution of Agriculture to Gross Domestic Product (GDP) is 42.1\%, NPC [2]. There is need for Nigeria to tap into the potentials of corporate agriculture. The expectation is that corporate agriculture could bring fortunes; help diversify the rural economy, increase industrial capacity utilization, create jobs, improve agricultural productivity and eliminating extreme poverty and hunger. The problem of this research is summed thus:

1) Unsustainable management of agricultural resources in Nigeria.

2) Adequate consideration and policy incentives have not been given to the private sector's corporate investment in Nigeria's most endowed sector-agriculture.

3) There are difficulties in assessing credit facilities for investment in agriculture.

4) Lack of adequate capital for the small-holder peasant farmers.

\subsection{Literature Review}

A study by [3] examined the effect of other channels of growth on the decrease in poverty and the overall growth rate in six low income countries of Africa. The findings of that research conclude that industrial growth is less effective in reducing poverty than agricultural growth. Nigerian agriculture can perform better in creating jobs if the sector is industrialized, diversified, and creating surplus value added in the chain. Nigeria needs agricultural revolution and industrialization on a country-wide basis. Corporate agriculture is a large scale business or commercial organization. It requires sourcing of capital from the sale of stocks and shares or by long-term borrowing through the sale of bonds or through giving mortgage or any combination of these methods. The shares or stocks represent equity interests, while bonds are evidences of creditors' interest [4]. In many developing countries, corporate farms were operated by foreign companies in the form of plantation. This was true of rubber, cotton, and oil palm plantations in Nigeria; tea, teak, coffee, tobacco plantations in many countries of South East Asia, South and Latin America and Africa. Many of such plantations were large scale enterprises under extensive land concessions, with the nationals of the countries working as paid laborers and the harvests exported to feed industries abroad. Nigeria is facing a global competitive market structure in agriculture. There is imminent food crisis given the population pressure. Food quality and quantity are on the decline. There are also environmental challenges; climate change-changes in temperature, precipitation, sea level, extreme weather conditions, floods, droughts and heat waves which represent major challenges for the small holder farmers operating with primitive technology. Corporate agriculture could pull capital together to afford agricultural technology innovations for large scale fisheries, livestock, fruits, vegetables and grains, as well as value-added agricultural industry. Corporate agribusiness has many advantages which include economies of scale, extensive research and development, diseases and pest control, efficient processing with high quality produce, efficient sales organization etc. Globally, agriculture is being researched, resourced, developed and financed as a business. Wassily Leontief developed strategies for the industrialization of Florida citrus industry to the benefit of small citrus farmers through the control of distribution and processing. Also developed was the strategy for the indu- 
strialization of America's wheat-to-consumer chain as well as soya bean market for animal feed. The benefits were agricultural efficiency, commercialization and economies of scale. Starting with the development of commercial hybrid double-cross seed corn varieties by the public sector in the 1930s, the private sector has assumed an increasing role in genetic improvement and seed reproduction in developed countries [5]. The Rockefellers' and Ford's Foundations in the 1970s have had significant impact on the transformation of American agriculture into more efficient corporate agriculture. This has had global influence on agribusiness. Taking China as another instance, the rural income distribution in China was worse than Nigeria in the period before 1978 when the Chinese Opening Up Policy became effective. It began to change following the household responsibility system (HRS), otherwise known as the privatization of agricultural production in the 1980s. China has about $22 \%$ of the world's population, but with only $9 \%$ of the world's cultivated land [6]. In terms of land mass and favorable weather suitable for corporate agriculture, Nigeria is better endowed than China. However, China's agribusiness is all over China and across Africa. From the period of HRS in the 1980s, the resources devoted to agricultural science and technology in China have expanded rapidly till date. China now ranks amongst the top countries in total R\&D spending and the number of researchers [7]. The Chinese breakthrough in hybrid rice forms a significant share of the competitive advantage of China's agribusiness. Corporate agricultural enterprises in China (with government policy support) have assisted in transforming the production technology of peasant farmers, lifting millions out of poverty in just a decade [8].

\subsection{Theoretical Framework}

The theoretical framework of this study is anchored on three theories: the Portfolio Theory, the Efficient Market Hypothesis (EMH) and Cost of Capital Corporate agricultural investment in Nigeria has expected returns measured by the risk involved. Risk is the danger or uncertainty in the midst of opportunity. The opportunity refers to returns or gains or the expected profits. Contextually, the returns refer to the actual or expected gains from corporate agriculture, measured as:

$$
R=\frac{C G+D}{I S P} \text { where } R=\text { risk, } C G=\text { Capital Gain, } D=\text { Dividend and } I S P=\text { Initial Share Price. }
$$

\subsubsection{The Portfolio Theory}

The pioneering effort in developing this theory is credited to [9] [10]. An investment portfolio is a collection of income-generating assets that have been purchased to meet a financial objective, [11]. Share (security) analysts employ this fundamental approach by relying on companies' estimated future earnings and dividends. The principal objective of the analysis is to identify mispriced stocks. Portfolio theory deals with how risk-averse investors can construct portfolios to optimize or maximize expected returns based on a given level of market risk. The theory states that rational investors are averse to taking increased risk, unless they are compensated by an adequate increase in expected returns. The theory further states that for any given expected returns, rational investors will prefer a lower level of risk. Where offered the same level of risk, they will prefer an investment with higher expected returns. According to the portfolio theory, a set of "efficient portfolios" can be constructed from which an investor can choose the most appropriate for his/her risk profile. The portfolio which offers the highest expected returns for a given level of risk is regarded as efficient or optimal portfolio. The optimal portfolio for Nigeria's corporate investors is agricultural value-added investments.

\subsubsection{Efficient Market Hypothesis (EMH)}

[12] and [13] established the theoretical basis of EMH. It was further propounded by [14] and [15]. EMH is a pillar of modern finance. The theory states that an efficient financial market is one which prices incorporate all available public and private information about an industry or company. Furthermore, the theory emphasizes an efficient financial market that gets capital from the surplus spending unit to the deficit spending unit with profitability but minimized risk. If the Nigerian economy must have effective demand and supply of capital, and invest optimally, the allocation of capital in the Nigerian Stock Exchange (NSE) should be done in such a manner that capital gets to those who can make good use of it to generate the highest returns. The potential for highest returns lies not in petroleum or imports, but in the agricultural industry local content. Agro-allied corporate industries with the most promising investment opportunities should have access to the Nigerian stock exchange market. Agricultural enterprises should be registered and traded in the NSE. They should have access to needed 
finance to accomplish the federal government vision of agricultural sector transformation and job creation. Nigeria agriculture has potential in providing needed raw materials for smooth industrialization. When funds are channeled to areas of comparative advantage such as agriculture, the market is said to be allocationally efficient as it adjusts to new information. An empirical analysis of the EMH is linked with the Capital Asset Pricing Model (CAPM) ([16] and [17]), expressed based on the equation:

$$
E(R i)=R f+\beta i[e(R m)-(R f)] .
$$

where:

$E(R i)=$ The expected average returns on the assets in portfolio(i),

$R f=$ The risk-free rate of return,

$e(R m)=$ Expected average returns on all assets,

$B i=$ The beta coefficient of the asset or portfolio(i). It is thus a measure of the risk in the asset or the portfolio. The set of information available at the NSE show that corporate agricultural companies are yet to be sufficiently listed at the NSE.

\subsubsection{The Cost of Capital Theory}

The financial cost of capital from the theory of the firm explains that the objective of the firm is to maximize profit in order to maximize the share value and vice versa. The value of the firm's shares depends on the profit or earnings, the costs and the discount rates. In order to maximize the profits and share value, both transaction cost and the discount rates have to be minimized. The discount rate by definition is the rate at which the financial market is willing to exchange one naira today for one naira in the future, it is the present value of future earnings. This is referred to as interest rate or generally as the cost of capital. There are therefore two types of cost associated with the financing decisions of corporate firms; the cost of raising the finances required from the capital or money market; the interest rate and the transaction costs. The later include registration fees, the underwriting fees, the issuing house commission and the stock exchange commission. The magnitude of these costs depends on the extent of imperfection and competition in the financial market. The Nigerian financial market is imperfect and competitive. Consequently, transaction costs are not zero. The size and magnitude of costs are also affected by the large amount of capital required for corporate agriculture [3]. This affects the expected profit from large scale agricultural investment. They could as such, affect the share value of the corporate enterprise. Since the costs are fixed in proportion, the new firm could do nothing to influence them. It is only the corporate financial policy of the government could adjust the transaction costs for the financial health of the economy. This is part of the monetary policy for macroeconomic stability. The second type of cost is the opportunity cost of capital which is used in discounting future sums to their present value. It is the cost of forgone alternative investments of capital or the loss of profit associated with forgone alternatives; such as the investor lending such capital to the financial market at a certain interest rate. The high transaction costs are a concern for the corporate enterprise because they act as impediments, excluding enterprises from raising capital in the capital and money markets. Similarly, the bigger the discount rate, all things being equal, the smaller will be the net present value of shares, stocks and bonds. This increases the risk of investment in corporate agriculture as new entrants evaluate the uncertainties associated with returns to the enterprise. Government financial policy should favor agriculture in a way that the corporate enterprise can choose a combination of types of capital that have the lowest cost advantages.

\section{Methodology}

In the methodology, we use secondary data. We use descriptive statistics and simple percentages for evaluation. Secondary data from the Nigerian Stock Exchange are collected, sorted, classified and used for the analysis, with extensive literature review. We undertake an analysis of price per share and returns on 20 most capitalized companies in the Nigerian Stock Exchange. The objective is to measure the number of corporate agricultural enterprises in Nigeria listed among the top 20 in the NSE. The NSE was founded in 1961, classified as an emerging market. It has over 260 listed firms cutting across many industries and a number of trading branches in some Nigerian cities. However, agricultural enterprises are yet to take a center stage among the 20 most capitalized companies. Agricultural industry is seen as the highest job creator in Nigeria. This analysis covers the mean, standard deviation, variance, and covariance, [18] and [14]. The higher the standard deviation, the riskier 
the investment, and the higher the expected returns. The variance is the average squared deviation in the sample, while the sample covariance of 20 most capitalized companies is a measure of association between the Nigeria capital market (X) and corporate agriculture(Y) for the period under study. This is presented in Table 1 and Table 2.

$$
\begin{aligned}
\operatorname{Cov}(X, Y) & =\frac{1}{n}\left[\left(X_{1}-\bar{X}\right)\left(Y_{1}-\bar{Y}\right)+\ldots+\left(X_{n}-\bar{X}\right)\left(Y_{n}-\bar{Y}\right)\right] \\
& =\frac{1}{n} \sum_{i=1}^{n}\left(X_{i}-\bar{X}\right)\left(Y_{i}-\bar{Y}\right) .
\end{aligned}
$$

Table 1 shows the closing price per share for each of these 20 companies. The differences between opening and closing share prices for the year constitute the capital gain/loss for the year. In all 20 most capitalized companies, none is agricultural, especially in the forward linkages. However, the agricultural industry is Nigeria's comparative advantage. Let us therefore observe the security returns for these 20 most capitalized companies in Nigeria as at December, 2014, as presented in Table 2.

In Table 2, Security return represents the return on each share incorporating the dividend paid and the capital appreciation or loss during the period. The standard deviation (SD) indicates the variability of the stock's return. While the co-variance is the final measure of the stock's returns variability since all the stocks have different means. Agricultural industries are hardly listed among these stocks. The table shows that there is variability of returns accruing to capital. The risk of a company's earnings is measured in terms of variability or co-variability using a statistic known as the variance or the covariance. The discount factor is represented by R\%. The overall variability in returns show that the selected firms have not made reasonable profits given that the comparative and absolute advantages lie in the agricultural industry yet untapped.

\section{Discussion of Findings}

The socioeconomic and cultural characteristics of Nigeria's rural areas where most of the agricultural endowments

\begin{tabular}{|c|c|c|c|c|c|c|c|c|c|c|c|c|}
\hline & Year & 2004 & 2005 & 2006 & 2007 & 2008 & 2009 & 2010 & 2011 & 2012 & 2013 & 2014 \\
\hline $\mathrm{S} / \mathrm{N}$ & Company & & & & & & & & & & & \\
\hline 1 & Access & 3.00 & 2.99 & 6.93 & 23.0 & 7.0 & 7.6 & 9.5 & 4.8 & 9.05 & 9.59 & 9.38 \\
\hline 2 & Dangote & 100 & 104 & 115 & 105 & 116 & 118 & 120 & 111 & 128 & 219 & 212 \\
\hline 3 & Ecobank & 7.24 & 5.03 & 5.01 & 7.95 & 28 & 10.6 & 3.6 & 1.98 & 11.3 & 16.2 & 13.6 \\
\hline 4 & FCMB & 5.18 & 5.11 & 4.09 & 18.9 & 5.7 & 7.01 & 7.5 & 4.18 & 3.75 & 4.14 & 3.93 \\
\hline 5 & F. Bank & 23.6 & 32 & 33.5 & 44.7 & 21.1 & 14.1 & 13.7 & 8.9 & 15.7 & 16.3 & 16.2 \\
\hline 6 & Flour. Ml & 16.6 & 25 & 65 & 82.6 & 32 & 36 & 69 & 65.5 & 65 & 87 & 74.3 \\
\hline 7 & GTB & 11.7 & 12.4 & 18.2 & 34.6 & 15.5 & 15.5 & 18 & 14.3 & 23 & 27 & 25.3 \\
\hline 8 & Guiness & 117 & 96 & 108 & 130 & 99.5 & 128 & 191 & 250 & 275 & 236 & 248 \\
\hline 9 & Lafarge & 11.3 & 17.3 & 54 & 79.8 & 25.5 & 30 & 40.7 & 43.3 & 58.5 & 115 & 111 \\
\hline 10 & Nestle & 150 & 187 & 235 & 277 & 182 & 240 & 369 & 446 & 700 & 1200 & 141 \\
\hline 11 & Ng. Brew & 42.8 & 38.8 & 37.3 & 49 & 41 & 53 & 77.1 & 94.4 & 147 & 168 & 151 \\
\hline 12 & $\mathrm{PZ}$ & 11.6 & 16.3 & 26 & 26.3 & 11.2 & 25 & 31.5 & 28 & 28 & 37 & 36.5 \\
\hline 13 & Stanbic & 4.2 & 4.57 & 7.05 & 20 & 11 & 7.47 & 9.2 & 8.3 & 11 & 21.4 & 23.5 \\
\hline 14 & Total Ng & 182 & 183 & 185 & 180 & 194 & 149 & 234 & 188 & 121 & 170 & 183 \\
\hline 15 & UACN & 14.2 & 17 & 26.5 & 51 & 35 & 36.8 & 37 & 31.2 & 42 & 67 & 58.5 \\
\hline 16 & UBA & 9.05 & 13 & 25.3 & 49.3 & 13.2 & 10.8 & 9.15 & 2.59 & 4.56 & 8.9 & 9.76 \\
\hline 17 & Uniliver & 15.5 & 20.5 & 12.5 & 22 & 10.4 & 18.5 & 27 & 29 & 46.5 & 53.8 & 62.4 \\
\hline 18 & Union Bank & 21 & 25.5 & 23 & 43.1 & 15.2 & 6 & 4.2 & 10.6 & 7.35 & 9.63 & 10.9 \\
\hline 19 & Zenith & 15.7 & 16.5 & 24.4 & 46.1 & 22 & 13.6 & 15 & 12.2 & 19.5 & 27.4 & 30.4 \\
\hline 20 & Cadbury & 59 & 62.5 & 32.5 & 37 & 26 & 10.5 & 25.6 & 11.4 & 29 & 59 & 58.4 \\
\hline
\end{tabular}

Table 1. Closing price per share for 20 most capitalized companies in Nigeria 2004-2014

Source: Nigeria Stock Exchange. 
Table 2. Security returns for 20 most capitalized companies in Nigeria as at December, 2014.

\begin{tabular}{|c|c|c|c|c|c|c|c|c|c|c|c|c|c|c|}
\hline $\mathbf{S} / \mathbf{N}$ & Company & & 2006 & 2007 & 2008 & 2009 & 2010 & 2011 & 2012 & 2013 & 2014 & Mean & STD & $\mathrm{CoV}$ \\
\hline 1 & A & $\mathrm{R} \%$ & 012 & 0 & -23 & 1 & 2 & 0 & -1.5 & 6 & 66 & -0.3 & 0.9 & -2.9 \\
\hline 2 & Dangote Cement & $\mathrm{R} \%$ & -0.65 & 0.13 & - & - & - & - & - & - & - & -0.23 & 38.2 & -1.64 \\
\hline 3 & Ecobank & $\mathrm{R} \%$ & 0.48 & 0.44 & 0.21 & -2.34 & 0.83 & 1.32 & 0.79 & -3.19 & 0.19 & -0.74 & 2.14 & -2.91 \\
\hline 4 & FCMB & $\mathrm{R} \%$ & 0.03 & 0.23 & -3.53 & 0.72 & 0.22 & -0.02 & 0.45 & 0.21 & -0.02 & 0.21 & 0.24 & 1.12 \\
\hline 5 & F.Bank & $\mathrm{R} \%$ & -0.29 & -0.02 & -0.30 & 0.55 & 0.40 & 0.03 & 0.40 & -0.88 & 0.03 & -0.08 & 0.54 & -6.60 \\
\hline 6 & Flour. Mls & $\mathrm{R} \%$ & -0.46 & -1.56 & -0.26 & 0.82 & 0.11 & -0.86 & 0.06 & 0.09 & -0.34 & -0.09 & 0.21 & -2.37 \\
\hline 7 & GTR & $\mathrm{R} \%$ & -0.08 & -0.39 & -0.87 & 0.80 & 0.05 & -0.08 & 0.26 & -0.51 & -0.11 & -0.12 & 0.38 & -3.31 \\
\hline 8 & 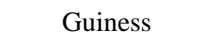 & $\mathrm{R} \%$ & 0.21 & -0.08 & -0.16 & 0.28 & -0.21 & -0.43 & -0.26 & -0.06 & 0.17 & -0.05 & 0.21 & -4.00 \\
\hline 9 & Lafarge & $\mathrm{R} \%$ & -0.50 & -2.06 & -0.46 & 0.69 & -0.17 & -0.35 & -0.04 & -0.33 & -0.91 & -0.43 & 0.44 & -1.03 \\
\hline 10 & Nestle & $\mathrm{R} \%$ & -0.18 & -0.20 & -0.14 & 0 & -0.25 & -0.49 & -0.18 & -0.53 & -0.88 & -0.48 & 26 & -0.58 \\
\hline 11 & Ng. Brew & $\mathrm{R} \%$ & 0.19 & 0.08 & -0.25 & 0.23 & -0.25 & -0.39 & -0.21 & -0.53 & -0.12 & -0.29 & 0.21 & -0.74 \\
\hline 12 & - & $\mathrm{R} \%$ & -0.33 & -0.58 & -0.08 & 0.60 & -1.16 & -0.23 & 0.14 & 0.02 & -0.28 & -0.04 & 0.21 & -5.25 \\
\hline 13 & Stanbic & $\mathrm{R} \%$ & -0.04 & -0.50 & -1.74 & 0.47 & 0.34 & -0.18 & 0.11 & -0.20 & -0.93 & -0.34 & 0.53 & -1.57 \\
\hline 14 & Total Ng & $\mathrm{R} \%$ & 0.03 & 0.02 & 0.08 & -0.03 & 0.29 & -0.52 & 0.23 & 0.42 & -0.34 & 0.11 & 0.39 & 3.72 \\
\hline 15 & UACN & $\mathrm{R} \%$ & -0.14 & -0.50 & -0.86 & 0.38 & -0.05 & 0.09 & 0.21 & -0.30 & -0.56 & -0.22 & 0.39 & -1.80 \\
\hline 16 & UBA & $\mathrm{R} \%$ & -0.37 & -0.87 & -0.91 & 0.74 & 0.24 & 0.16 & 0.79 & -0.57 & -0.84 & -0.21 & 0.87 & $-4,21$ \\
\hline 17 & niliver & $\mathrm{R} \%$ & -0.28 & 0.40 & -0.73 & 0.56 & -0.88 & 0.39 & -0.17 & -0.56 & -0.13 & -0.24 & 0.28 & -1.21 \\
\hline 18 & Union Bank & $\mathrm{R} \%$ & -0.17 & 0.14 & -0.84 & 0.66 & 0.70 & 0.62 & -1.29 & 0.51 & -0.21 & -0.33 & 0.90 & -2.76 \\
\hline 19 & Zenith & $\mathrm{R} \%$ & 0.02 & -0.41 & -0.85 & 0.56 & 0.40 & -0.04 & 0.25 & -0.47 & -0.32 & -0.18 & 0.38 & -2.14 \\
\hline 20 & Cadbury & $\mathrm{R} \%$ & -0.08 & 0.54 & -0.01 & 0.39 & 0.58 & -0.78 & 0.80 & -1.5 & -0.71 & -0.11 & 0.74 & -6.87 \\
\hline
\end{tabular}

Source: Authors’ computation, 2015.

are located are yet to be made conducive with supportive policies for corporate investment. Corporate agricultural industry cannot succeed in accelerating rural development and employment unless it is supported by adequate infrastructural facilities such as good rural roads, electricity, functional banks, water supply, hospitals and communication infrastructure. Capital Investment is the sacrifice of current consumption for future gains. It is divided into real estate investment (in land, housing, machineries, factories, trademarks, patents, technical knowledge etc.) and financial investment (i.e. the purchase of stocks, shares, bonds, debentures) from a firm traded in the capital market for long term financing. Nigeria has huge potentials of becoming the largest and most profitable agricultural industry in Africa. The opportunities exist in cocoa, rubber, oil palm, cashew, mango, citrus, pear, pineapple, tobacco, cotton, grains, beans and cassava. Other areas of promising investment in corporate farming in Nigeria are fresh water fish farming, mushroom cultivation, raising poultry and rabbit. All these investments require supportive infrastructure. Corporate agriculture can reduce poverty in two major ways. Firstly by creating jobs. Secondly, since these agricultural resources are rural-specific, it will create rural infrastructure, reduce rural-urban migration and speed off rural development in Nigeria. Nigeria has huge potentials for expanding foreign exchange earnings from agriculture. The nature endowments of agricultural resources are renewable and sustainable. Sustainable agriculture is a key to rural development. It is labour-intensive and has the potential of creating jobs for millions of Nigerian youths, thereby promoting economic development and reducing poverty. However, the innovation and investment needed in the sector are still missing. There are successful indigenous entrepreneurs in cement, sugar, flour, but in corporate farming. Agricultural innovation is driven by competitive market structure, food crisis (decline in food quality and quantity), environmental challenges (disasters, climate change, drought, and heat), science and technology, political factors and infrastructure. These requirements have sophisticated beyond the reach of subsistence peasant farmers or informal sector operations. The majority of peasant farmers do not have the capacity to adopt new technology because they are capital-intensive. They also lack collaterals and have difficulties in obtaining loans for large-scale production. It is corporate investment that has the potential for sustainable agricultural development in Nigeria. According to [19], the investors have a claim on the firm's real assets and the income that those assets can produce. Nigeria's 
corporate farm management should have choices of either using joint stock equity or debt financing [20]. These investments have a defined process for efficient allocation in terms of initial decision to invest, the types of investment, the amount to be committed to the investment, where and when to invest. Michael Porter's diamond model provides interlinked advanced factors for competitive advantage; the strategy, structure and rivalry of enterprise, demand conditions, related supportive industries, government, etc. [21]. These factors motivate and pressurize the Nigerian agricultural enterprises to constantly improve their competiveness, productivity and innovation. The related industries (upstream and downstream) facilitate exchange of information and innovative ideas. Government only needs to act as a catalyst and partner to enterprise innovation. There is the need for preferential license fee and royalty for farm entrepreneurs in Nigeria. There is need for the extension of some new technologies to farmers by training courses and consultation. There is also need to partner with international agribusiness entrepreneurs in a win-win contract for the development of corporate agriculture in Nigeria. The Forum on China-Africa Cooperation offers a window of opportunity for agricultural trade deals, since China's agricultural technology are suitable for Africa and Nigeria in particular.

Profitable investment in Nigeria's agriculture begins with the analysis of the sources of new opportunities. Agricultural innovation has been an instrument of foreign policy, promoted by the Food and Agriculture organization (FAO) of the United Nations, the World Bank programs in Latin America, Asia and Africa. The Green Revolution of the 1950s, 1960s and 1970s, where America' hybrid forms of wheat, corn, rice, and livestock was commercialized and internationalized is a good model for Nigeria, the largest economy in Africa. Furthermore, the current rise in food prices has heightened the consumer price index (CPI), which in turn caused inflation and making the economic crisis difficult to solve. Nigeria's economy is feared by experts to enter depression in 2016. This is because the macroeconomic activities do not attach relevance to agricultural value chain as it attaches to petroleum industry. A new set of innovation is needed to solve the food importation, unemployment and poverty reduction by 2030. A kind of innovation that results in high economic benefits for the peasant is needed. We are aware of the predominant role of peasant agriculture in rural transformation. Rather than crowding out the peasant system, corporate agriculture will have complementary advantages and positive multiplier effects on peasant agriculture. Rural surplus labor will be absorbed; there will be training for peasants in agricultural technology. There will be technological spillover, transfer, adoption and innovation. Rural infrastructure will improve generally to the benefits of the peasant farmers. However, the issues of land grabbing, environmental conservation and land reforms should be taken seriously. Peasant farmers would have the opportunity to diversify their income sources and livelihoods. They would have the opportunity to work on their farms and still take part-time jobs in the farm factories at the same time. Those entrepreneurs who rent their pieces of land for corporate businesses would also constitute additional sources of income. Petty-trading will boom. There will be general improvement in commercial activities in the rural areas, leading to inclusive growth. Corporate social responsibilities will improve rural education, health and sports. It will also support input-related industries in fertilizers, feeds, seeds, chemicals, irrigation, communication infrastructure and electricity.

Presently, Nigeria's small farm holder production capacity is highly constrained; causing a rise in producer's price index (PPI), food supply is in short of food demand. Poor planning and wasteful management of resources (land, chemicals, manpower, money, machines etc.) is unsustainable. The Nigerian agro ecosystem is not resilient, self regulating, it is highly dependent on imported inputs, and profitability is hardly maintained. The public sector, through successive governments has attempted to tackle poverty through agricultural projects and policies recommended by the World Bank such as the Integrated Agricultural and Rural Development Project, Operation Feed the Nation, Green Revolution, River Basin Authorities etc. However, what was missing is private partnership with these programs. This was the major reason for their failures. The projects did not look at agriculture as a business that could be listed in the Nigerian Stock Exchange, requiring huge private-public sector investments. Corporate agriculture has potentials for rural development, employment and poverty reduction in Nigeria. Risk diversification to corporate agriculture in Nigeria is rational, given the macroeconomic instability caused by oil price volatility. Diversification in this context implies the spread of investment to other sectors of the economy. The principal aim of diversification is to reduce the risk associated with monoproduct and volatile oil sector. This is in line with the opinion of scholars such as [4] [22]-[25]. The employment and income effect from oil and agricultural sectors in Nigeria are not the same. The variance is in support of diversification towards labour-intensive agriculture with higher propensity for gains. One way of transforming Nigeria's economic structure is by promoting non-traditional exports through industrialization, beginning from agricultural industrialization. It is labour-intensive and Nigeria has comparative advantage in agricultural industry. 


\section{Corporate Agriculture and Sustainable Development}

Increased production of crops and livestock for consumption and exports earnings is an enviable feature of sustainable development. Sustainable economic development according to [26] is the underlying principle for sustaining finite resources necessary to provide for the needs of future generations. He posits that sustainable economic development is a progress that envisions a desirable future state for human societies in which living conditions and resource use continue to meet human needs without undermining the integrity, sustainability, stability and beauty of natural biotic system. In his opinion [27], views sustainable development as development that meets the needs of the present without compromising the ability of future generation to meet their own needs. [28] sees sustainable economic development as the sustained, concerted actions of policy makers and communities that promote the standard of living and economic health of a specific area. Such actions can involve multiple areas including development of human capital, environmental sustainability, social inclusions, safety, literacy and other initiatives. [29] also sees sustainable economic development as a multi-dimensional process involving changes in structures, attitude, and policies, as well as sustained acceleration of growth, reduction of inequalities and eradication of absolute poverty. In the same view, Dudley [30] asserted that if poverty, unemployment and inequality decline considerably, it shows a period of sustainable development. But if any or all of these indices are growing, we cannot refer to such as sustainable development even if the per capita income doubles [31], describes sustainable economic development as the attainment of ideas of modernization, such as increases in productivity, social and economic equalization, modern knowledge, improved institutions, attitudes and a rational coordinate system of policy measure that can remove host of undesirable conditions in the social system that have perpetuated a state of underdevelopment. Sustainable economic development usually revolves round the notion of economic growth, modernization, distribution, improved agricultural techniques and socioeconomic transformation [32]. The international Labor Organization [33] expresses sustainable economic development as the satisfaction of basic needs of the poorest group of people in a nation. The satisfaction of basic needs means meeting the minimum requirements of a family for personal consumption, food, shelter and clothing. It implies access to essential services such as safe drinking water, transportation, health and education. Therefore, sustainable economic development is considered to be a multidimensional process involving structural, attitudinal and institutional changes as well as sustainable growth, reduction of inequality, elimination of absolute poverty and improved standard of living. In order words, it relates to the capacity of a nation to promote, generate and sustain its resources with national frontiers for the improvement and advancement of her citizens.

\section{Conclusion}

Nigeria has rich potentials for agro-allied industrialization and rural development. A pull of capital investment is required to develop the Nigeria's agricultural industry which the small holder farmers cannot provide. Structural unemployment is the type that best explains the Nigerian situation. It arises from markets' and government's failures. The demand for imported agricultural products is affected by underutilization of Nigeria's agricultural production capacity. There is excess demand for imported foods, including clothing, cars, furniture, flowers, rubber products etc. Government's failures arise from inefficiency, corruption and mismanagement. Markets' failures arise from output market, capital market and factor market in the form of rigidities, distortions and immobility of resources. Consequently, government and markets have failed to allocate resources efficiently which result in unemployment. Government policy and private-public partnership are required for full utilization of Nigeria's comparative and absolute advantages in agriculture. The larger the size of farms, the easier farm entrepreneurs could obtain external funding in the stock market and financial institutions. The output of corporate agriculture is estimated to include higher yields, employment, and improved core competence through technology adoption, commercial linkages, profits, income, food security, self-reliance and sustainable rural development. It will bring about investment in the development of large scale adoption of high yield varieties (HYVs) such as oil palm, cocoa, livestock, fisheries, rice, corn, soybeans, wheat and cotton which will facilitate industrialization. Furthermore, it will enlarge the scope of production, processing, management and exports. When properly developed, corporate farming can reduce imports by distributing fresh products to supermarkets, airport perishable cargo, schools, hospitals, military bases, hotels, restaurants and churches. Product lines are profitable in freeze-dried vegetables, fruits, fruit juices, milk, yogurts, health drinks, meat and eggs. Corporate agriculture will improve agricultural research and biotechnology techniques, reduce farm costs, expand input and output market for agriculture, feed supplies and improved seeds. It will diversify peasant livelihoods, create jobs, food 
security, and reduce poverty and overall socioeconomic development. Nigeria can achieve food security and also contribute to food security in other countries through exports and foreign exchange.

\section{Recommendation}

Nigeria has urgent need for innovations in agricultural technology, market and institutions. There are many innovations and competition in the agribusiness that cannot be managed and sustained by small-holder peasant farmers in Nigeria. These require corporate agriculture. Policies on public/private agricultural R\&D in Nigeria should include systematic technology management, protection of intellectual property rights and efficient application through technology transfer. Knowledge-based economy is a global trend and it stimulates the transformation of traditional agriculture toward industrialization. Import substitution is an inward-looking strategy that safeguards domestic producers from competition posed by imported products of developed countries, using trade and tariff barriers. On the other hand, export policy is an outward looking strategy that connects the domestic economy to the global market by encouraging exports of domestically manufactured goods. Nigeria should exploit agricultural opportunities, be aggressive in both strategies. There exists a large market in Nigeria for agro-allied and manufactured goods. Other necessary requirements in the link of agricultural industry chain include the port authority, suppliers of raw materials, premix producers, compound feeds manufacturers, seeds producers, meat processing and aquaculture, research in agricultural technology with focus on increased productivity in quality and quantity. Diversifying Nigeria's agriculture through corporate farming will reduce the risks of importation of foods. Government agricultural policy can further be fine-tuned to favor private investors locally and internationally. There should be strict compliance with monitoring of imported food products by Nigerian Customs, Standard Organization of Nigeria (SON), Manufacturers Association of Nigeria (MAN), Consumer Protection Council (CPC) and the National Agency for Foods, Drugs Administration and Control (NAFDAC). This will eventually help to create foreign investment in Nigeria's agricultural industry. When investors recognize that a huge potential market exists for agricultural goods and services produced in Nigeria, they will set up related industries, creating abundant employment locally. The potential for cash crops that are yet fully tapped include cassava, cocoa, coffee, cocoanut, sesame seed, rice, nutmeg, pistachios, garlic, Macedonia nuts, rubber, peanuts, cashew, oil palm, beans, sweet potatoes, cinnamon, corn, cotton, timber, and various kinds of fruit trees and vegetables. As a rural development strategy, we also recommend a bridge in infrastructure gap between rural and urban geography in a comprehensive rural-urban integration program.

\section{References}

[1] CIA (2014) The World Fact Book. Central Intelligence Agency. http://www.cia.gov/library/publications/Nigeria_economy.html

[2] NPC (2013) National Planning Commission Blue Print on Vision 20:2020. http://www.nationalplanning.gov.ng/docs/nationalplans/agriculturefoodsecurityntwgreport.pdf

[3] Diao, X., Hazell, P. and Thurlow, J. (2009) The Role of Agriculture in Africa's Development. World Development Report (WDR), 38, 1375-1383. http://dx.doi.org/10.1016/j.worlddev.2009.06.011

[4] Orebould, P. and Poon, K. (1993) Capital: An Essential Variable in the Production Function. Review of Economics and Statistics, 2, 48-57.

[5] Aston, J.M. (2010) The Benefits from Agricultural Research and Development, Innovation and Productivity Growth. OECD, Food, Agriculture and Fisheries Working Paper, No. 31. http://dx.doi.org/10.1787/5km91nfsnkwg-en

[6] Jingyuan, X. (2011) Agricultural Production and Agro-Tech, Extension in China. Asian Pacific Economic Cooperation (APEC), Beijing, 18 November 2011, 60-72.

[7] OECD (2011) China’s Emergence as a Market Economy: Achievements and Challenges. http://www.oecd.org/china/47408845.pdf

[8] Eneji, M.A., Song, W. and Oko, S.U. (2012) Benefits of Agricultural Enterprise Technology Innovation Capacity to Peasant Farmers in Rural Poor Areas. The Case of DBN Group, China. International Journal of Development \& Sustainability, 1, No. 2. http://isdsnet.com/ijds-v1n2-8.pdf

[9] Harry, R. (1959) The Theory of Investment Value. North-Holland, Amsterdam.

[10] Harry, R. (1952) Advances in Prospect Theory; Cumulative Representation of Uncertainty. Journal of Risk and Uncertainty, 5, 367-323.

[11] Ozoguz, A. (2009) Good Times or Bad Times? Investors’ Uncertainty and Stock Returns. The Review of Financial 
Studies, 22, 4377-4422. http://dx.doi.org/10.1093/rfs/hhn097

[12] Samuelson, P. (1965) Proof That Properly Anticipated Prices Fluctuate Randomly. Industrial Management Review, 6, 41-49.

[13] Mandelbort, P. (1966) Asset Pricing in Exchange Economy. Econometrica, 46, 1424-1445.

[14] Gordon, J.A., Sharpe, W.F. and Berley, V.J. (2007) Fundamentals of Investment. Prentice Hall, New Delhi.

[15] Joganathan, R. and Wang, L. (1996) The Conditional CAPM and Cross-Section of Expected Returns. Journal of Finance, 51, 3-53. http://dx.doi.org/10.1111/j.1540-6261.1996.tb05201.x

[16] Fama, F.E. and French, R.K. (1993) Common Risk Factors in the Returns on Stocks and Bonds. The Journal of Financial Economics, 33, 3-56.

[17] Fama, F.E. and French, R.K. (1996) The Cross-Section of Expected Stock Returns. The Journal of Finance, 47, 427467. http://dx.doi.org/10.1111/j.1540-6261.1992.tb04398.x

[18] Gordon, J.A. (1959) Dividends, Earnings, and Stock Prices. The Review of Economics and Statistics, 41, 99-105. http://dx.doi.org/10.2307/1927792

[19] Brealey, A.R., Myers, C.S. and Marcus, J.A. (2007) Fundamentals of Corporate Finance. 5th Edition, McGraw-Hill, New York.

[20] Maimako, S.S. and Moses, O. (2011) Financing Choices: A Test of the Pecking Order Theory. The Nigerian Accounting Horizon, 4, 21-39.

[21] Abubakar, M.A. and Maimako, S.S. (2014) Are Mutual Managers in Nigeria Worth Their Money? International Journal of Management Practice, 7, 298-308. http://dx.doi.org/10.1504/IJMP.2014.065228

[22] Evans, L.J. and Archer, H.S. (1968) Diversification and Reduction of Dispersion: An Empirical Analysis. The Journal of Finance, 23, 761-767. http://dx.doi.org/10.1111/j.1540-6261.1968.tb00315.x

[23] Wagner, H. and Lau, S.C. (1971) The Effect of Diversification on Risk. Financial Analysis Journal, 27, 48-53. http://dx.doi.org/10.2469/faj.v27.n6.48

[24] Statesman, M. (1987) How Many Stocks Make a Diversified Portfolio? The Journal of Finance and Quantitative Analysis, 22, 353-363. http://dx.doi.org/10.2307/2330969

[25] De Wit, D.P.M. (1998) Naïve Diversification. Financial Analysts Journal, 54, 95-100. http://dx.doi.org/10.2469/faj.v54.n4.2201

[26] Wagner, H. (2014) Institutional Reasons for Slow Economic Structure Transition, Serious Unemployment and Unjust Income Distribution. Management World Monthly, 6.

[27] Barbier, N. and Thaler, R. (2002) A Survey of Behavioral Finance. In: Constantinides, G., Harris, M. and Stutz, R., Eds., Handbook of the Economics of Finance, Elsevier, North Holland, 200.

[28] Adamu, F. (2008) Economic Globalization in Northern Nigeria. Annual Conference on Development, Scotland, 18 August 2008, 22-28.

[29] Todaro, M.P. (2005) Economic Development in the Third World. Longman, New York.

[30] Dudley, S. (2005) The Meaning of Development. World Society of International Development. International Conference on Human and Economic Resources, New Delhi, 8-14 April 2005, 327-385.

[31] Black, F. (1996) Fundamentals of Corporate Finance. 5th Edition, McGraw-Hill, New York.

[32] Friedman, M. (2001) Financial Statement Analysis. Prentice Hall, New York.

[33] ILO (2011) Estimates and Prospects of Economically Active Population: Methodology at Description. http://www.ilo.org/wcmsp5/groups/public/-----/wcms 213755.pdf 